\title{
Disclosing Information on Financial and Non-Financial Capitals in the Integrated Report: An Empirical Analysis of Financial Industry
}

\author{
Serena Santis ${ }^{1} \&$ Michela Bianchi ${ }^{2}$ \\ ${ }^{1}$ University of Campania “Luigi Vanvitelli”, Caserta, Italy \\ ${ }^{2}$ University of Roma Tre, Rome, Italy \\ Correspondence: Serena Santis, Department of Political Science “Jean Monnet” - University of Campania "Luigi \\ Vanvitelli”, viale Ellittico, 31, Caserta, Italy. E-mail: serena.santis@unicampania.it
}

Received: September 1, 2020

Accepted: October 3, 2020

Online Published: October 20, 2020

doi:10.5539/ijbm.v15n11p62

URL: https://doi.org/10.5539/ijbm.v15n11p62

\begin{abstract}
This study investigates how firms within the financial industry disclose financial and non-financial information in their integrated reports, by analyzing a sample of the banking sector published over five years (2014-2018). During the first phase, a content analysis methodology was conducted to investigate the disclosure level of six forms of capital, i.e., capitals. A principal component analysis then was implemented to reduce the dimensionality and investigate the relationship between capitals' information. The main findings show that during the observed period, the focus mainly is on financial capital, while information on non-financial capitals is underdeveloped. A relationship exists among all non-financial capitals, but not between financial and non-financial capitals. The paper contributes to the academic debate on the use of integrated reports (IRs) in practice, providing useful insights regarding financial and non-financial disclosure.
\end{abstract}

Keywords: disclosure; financial capital; financial industry; integrated report; non-financial capitals

\section{Introduction and Motivation}

This study aims to examine banks' integrated report (IR) disclosures during the 2014-2018 period by studying how these firms disclose financial and non-financial information, and whether disclosure provides a holistic view concerning different IRs' capitals.

A primary motivation for this study entails the heavy pressure that firms are experiencing to disclose financial and non-financial information, as well as communicate how they manage financial and non-financial capitals (Gray, 2006; Arvidsson, 2011; Eccles, Serafeim, \& Krzus, 2011; de Villiers, Rinaldi, \& Unerman, 2014; Manes-Rossi, 2018). Furthermore, in the European context, Directive 2014/95/EU introduced (for large public interest entities) the obligation to include, in the management report, "a non-financial statement containing information to the extent necessary for an understanding of the undertaking's development, performance, position, and impact of its activity, relating to, as a minimum, environmental, social, and employee matters; respect for human rights; (and) anti-corruption and bribery matters" (art. 1 - 19a). Therefore, the directive raises non-financial information to the same level as financial information, thereby overcoming the dichotomy between mandatory and voluntary information in the same way as the International Integrated Reporting Council (IIRC) Framework. Accordingly, the European Union (EU) directive would be capable of increasing corporate transparency and sustainable development (Muserra, Papa, \& Grimaldi, 2019). In this vein, IRs are attracting the attention of both researchers (Eccles \& Kiron, 2012; de Villiers et al., 2014; Higgins, Stubbs, \& Love, 2014; Dumay, Bernardi, Guthrie, \& Demartini, 2016; Rinaldi, Unerman, \& de Villiers, 2018) and practitioners (KPMG, 2012; EY, 2014; PwC, 2015). IRs intend to provide a complete picture of the value creation process by connecting financial and non-financial information in a single report (IIRC, 2013). To put it differently, disclosing information on financial and non-financial capitals should make it possible to identify their interconnections so that stakeholders need not search for this information in separate and disconnected documents (Adams \& Simnett, 2011; IIRC, 2013, p. 2; Melloni, 2015). Accordingly, reporting on financial and non-financial capitals is not an objective in itself, as it serves as a means through which firms can focus on the factors that are most important to the organization's underlying sustainability (IIRC, 2015). Previous studies have concentrated on intellectual capital's importance within IRs (Zambon \& Marzo, 2007; Abhayawansa \& Guthrie, 2010; EY, 2014; Melloni, 2015; Santis, Bianchi, Incollingo, \& Bisogno, 2019), investigating its 
contribution to value creation (IIRC, 2011). Furthermore, scholars have criticized the connection between what firms disclose in their reports and how they actually function (Brown \& Dillard, 2014; Stubbs \& Higgins, 2014; de Villiers, Venter, \& Hsiao, 2017). Melloni (2015) documented that firms tend to disclose information on intellectual capital opportunistically, in accordance with an impression management strategy, to improve their image. However, scholars have long highlighted the relationship between sustainable development goals, reputation, and financial performance (Miles \& Covin, 2000; Ambec \& Lanoie, 2008; Dwyer et al., 2009). This study adopts a wider approach by considering all six forms of capital (financial, manufactured, intellectual, human, social and relationship, and natural) as defined in the IIRC Framework, scrutinizing whether and how information disclosed about them is related.

A second motivation concerns the emphasis on the financial sector. Several banks in different countries have experienced important financial difficulties, often due to managers' unethical and risky behavior. This situation has caused further deterioration in trust among stakeholders, leading to a diffuse negative perception of them (Crotty, 2009; Buckley \& Arner, 2011; Helleiner, 2011; Nisha, 2016). Because of their crises/bankruptcies, many banking customers have incurred serious financial damage, and to support the sector, many banks worldwide have received financial support from governments. Consequently, providing information on non-financial capitals can become critical, as investing in human resources and developing social projects have been shown to improve relationships among relevant stakeholders (Freeman, 1994), as well as long-term financial performance (McGuire, Schneeweis, \& Branch, 1990). Furthermore, banking industries play key roles in nations' wealth, impacting economies in various ways and carrying several implications for economic growth (Demirguc-Kunt, \& Levine, 2000). In this process of value creation, stakeholders push to procure information other than financial data. Therefore, it is relevant to disclose non-financial information to increase trust among stakeholders (Strano et al., 2018; Venturelli et al., 2018; Directive 2014/95/EU 2014).

From a methodological perspective, a sample of 45 companies within the financial industry was investigated by analyzing their IRs during the 2014-2018 period, comprising 223 IRs. In a first step, a manual content analysis was conducted to collect and organize the information about disclosure on different forms of capital, i.e., capitals. A qualitative label was assigned to designate the level of disclosure for each capital. To investigate the relationship between capitals, an analysis of correlation and a principal component analysis were performed. Furthermore, a regression model was implemented to evaluate whether the sampled firms' profitability and size impact disclosure levels.

The main findings that emerged from the study are that a clear distinction must be made between level of disclosure on financial capital in a principal way and level of disclosure on non-financial capitals (manufactured, intellectual, human, social and relationship, and natural), as the latter remain under-investigated. Over time, greater attention has emerged only toward disclosure levels for human capital, but the information integration process seems to be evolving, even if it does not appear complete yet. Also, the relationship between capitals is ongoing. No relationship exists between financial and non-financial capitals, but a relationship exists among all non-financial capitals.

The remainder of the article is structured as follows. The second section provides a review of relevant literature on integrated reporting and defines the study's hypotheses. The third section illustrates the research methodology. The fourth section presents the results, which are discussed in the fifth and final section, which includes directions for future research and concludes the paper.

\section{Literature Review}

According to the IIRC, an integrated report is "a concise communication about how an organization's strategy, governance, performance, and prospects, in the context of its external environment, lead to the creation of value over the short, medium, and long term" (IIRC, 2013, para. 1.1). The IIRC Framework divides the capital into six categories, or capitals, viewing them as fundamental concepts strictly connected to the value creation process, although not all capitals are equally relevant or applicable to all organizations (IIRC, 2013, para. 2.16).

Both the content and purpose of an IR largely have been investigated over the past few years. Early extant literature has viewed IR as an informative tool, encouraging firms to consider their strategies' environmental and social impacts (Eccles \& Krzus, 2010; Eccles, Beiting, \& Saltzam, 2010; Eccles \& Saltzman, 2011; Eccles, Krzus, \& Watson, 2012). Furthermore, scholars have focused on the IR's characteristics by comparing it with traditional sustainability reports (Jensen \& Berg, 2012), while also investigating its origins and developments for professional and academic training (Owen, 2013). Other studies have provided model examples based on the description of capital and governance (Abeysekera, 2013), conducting practical analyses of content and form (Wild \& van Staden, 2013). 
Another research field relates to the factors that determine IR practices (Frias-Aceituno, Rodriguez-Ariza, \& Garcia-Sanchez, 2013a, 2013b; Garcia-Sanchez, Rodriguez-Ariza, \& Frias-Aceituno, 2013; Frias-Aceituno, Rodriguez-Ariza, \& Garcia-Sanchez, 2014; Sierra-García, Zorio-Grima, \& García-Benau, 2015). More recently, IR has been viewed as a fundamental way to help organizations disclose their journey toward reaching the United Nations' Sustainable Development Goals (Stacchezzini, Melloni, \& Lai, 2016; Adams, 2017; Busco, Granà, \& Izzo, 2018). Other studies have spotlighted (and tested empirically) the positive effects from (the quality of) IRs on the stability of a firm's relationship with its investor base (Serafeim, 2015), analysts' earnings forecast accuracy, the reduction of equity capital costs (Zhou, Simnett, \& Green, 2017), and firms' value (Lee \& Yeo, 2016; Barth, Cahan, Chen, \& Venter, 2017).

Many later extant studies examined two main critical aspects. First, several dealt with theoretical problems and concrete challenges due to different ways of applying and interpreting such reporting (Cheng, Green, Conradie, Konishi, \& Romi, 2014; de Villiers et al., 2014; Higgins et al., 2014; Brown \& Dillard, 2014; Van Bommel, 2014). Scholars strongly have criticized IRs' excessive business and investor focus at the expense of sustainability (Elkington, 2009; Milne \& Gray, 2013). Similarly, Flower (2015) criticized the IIRC approach, asserting that in the final version of the framework, the sustainability accounting was, de facto, abandoned. Furthermore, he emphasized the framework's weak prescriptive power, which could limit its influence on future practices in corporate reporting. Thomson (2015) noted the framework's weaknesses similarly, while Adams (2015), responding to Flower's paper, asserted that some of its problematic aspects are due to inadequacies in the measurement tools, also highlighting its potential to change corporate actors' thinking toward sustainability. Dumay, Bernardi, Guthrie, \& La Torre (2017) focused on possible barriers to implementing the IIRC Framework, as well as on possible ways to advance the framework, along with the areas that potentially may hinder its wider adoption and implementation. Camilleri (2017) has provided a critical review of key theoretical underpinnings that have anticipated the development of corporations' integrated disclosures.

Scholars also have noted the need to investigate disclosure reports' content to understand whether this new reporting approach's aims are realistic and achievable in practice. Accordingly, many studies have answered this call.

Several papers have examined emerging IR practices (Marx \& Mohammadali-Haji, 2014; Incollingo, 2014; Adams, Potter, Singh, \& York, 2016; Chersan, 2015; Eccles, Krzus, \& Ribot, 2015; Ahmed Haji \& Anifowose, 2017; Feng, Cummings, \& Tweedie, 2017; Beck, Dumay, \& Frost, 2017; Camodeca \& Almici, 2017; Chen \& Perrin, 2017; Dumay \& Dai, 2017; Gibassier, Rodrigue, \& Arjaliès, 2017), with some focusing on the application of the framework's guiding principles (Ruiz-Lozano \& Tirado-Valencia, 2016; Incollingo \& Bianchi, 2016; Mio, Fasan, \& Pauluzzo, 2016; Melloni, Caglio, \& Perego, 2017).

Recent IR literature reviews have developed insights into how IR research is developing, offering a critique on it and outlining its future opportunities (Dumay et al., 2016; Perego, Kennedy, \& Whiteman, 2016; de Villiers et al., 2017; Romolini, Fissi, \& Gori, 2017; Velte \& Stawinoga, 2017; Dumay, La Torre, \& Farneti, 2019; Vitolla, Raimo, \& Rubino, 2019), as well as suggesting unexplored directions for future studies (Comerio \& Tettamanzi, 2019). Notable among these is Rinaldi et al. (2018), who examine the overall IR journey as stated by IIRC to identify IR strengths and weaknesses, aspects that can be improved, and gaps that need to be filled.

Regarding the financial sector in particular, which is this paper's focus, a case study by Casonato, Farneti, \& Dumay (2019), which examined whether implementing IRs in an Australian financial services company enhanced disclosure quality, is a notable one among many. This research suggests that the IIRC Framework does not support disclosure, but rather legitimizes a company's activities for purposes of restoring its reputation.

In fact, among the main challenges that banks are facing nowadays, a need exists to re-build trust. The recent creation of the Integrated Reporting Framework (which was under revision at the time of the paper's writing) signals companies' willingness to react to the growing loss of trust in accounting emanating from global financial crises (Dumay et al., 2019).

"We live in a world of distrust" (Dumay et al., 2019), and people's confidence in businesses is failing due to the fact that it is not easy to understand which companies operate correctly and which do not. The latest Edelman Trust Barometer report registered a very modest three-point increase in trust in business globally, continuing a situation of general distrust in 10 countries out of 26 examined (Edelman Trust Barometer, 2019).

Scholars have called for further research regarding how firms implement IRs. The main scope is to understand how the linkages between the six capitals have been interpreted and to assess disclosure quality concerning both financial and non-financial capitals. In line with a specific research direction identified by Comerio \& Tettamanzi (2019), which requires investigating the relationship between financial performances and efficacy 
levels in integrating financial and non-financial information in a unified report, this study aims to investigate the following research questions:

RQ1: How do banks disclose information on financial and non-financial capitals in their IRs?

RQ2: Is there a relationship between disclosure of financial and non-financial information?

\section{Research Methodology}

This study investigates a homogeneous sample, examining firms within the financial industry that have published their IRs during the 2014-2018 period. The IIRC database contains 51 financial firms (researched on June 30,2019$)$. Four did not provide their IRs for all the selected years, so they were excluded from the sample. Moreover, one firm was included twice in the database (by using a long name and an acronym). Finally, another firm changed its name during the investigated period. Therefore, the final sample comprises 45 companies. A list of the selected companies is provided in Appendix A. (Note 1)

Once a database with companies' names was created, the IRs were downloaded from each company's website from 2014 to 2018. In the end, 223 IRs were gathered (one firm did not release a 2018 IR, and another one did not make its 2017 IR available). In relation to other studies, the principal strength of this research is the large, vast sample of over 200 IRs.

Table 1 provides geographical data on the sampled firms. It is worth observing that the vast majority (40\%) of the firms are based in Europe, followed by Africa and Asia. Residually, few companies come from America (North and South) and Oceania (Australia).

Table 1. Geographical area

\begin{tabular}{lll}
\hline Continent & No. & $\mathbf{\%}$ \\
\hline Europe & 18 & $40 \%$ \\
Africa & 12 & $27 \%$ \\
Asia & 8 & $18 \%$ \\
America & 4 & $9 \%$ \\
Oceania & 3 & $6 \%$ \\
Total & $\mathbf{4 5}$ & $\mathbf{1 0 0 \%}$ \\
\hline
\end{tabular}

The research methodology includes different steps.

The first step comprises carrying out a content analysis "to collect and organize information in a standardized format that allows the analyst to undertake inferential analysis on the characteristics and meaning of the recorded information" (Krippendorff, 2013). Content analysis is a research technique for the objective, systematic, and quantitative description of the manifest content of communication (Holsti, 1969; Krippendorff, 2013; Weber, 1990). Concretely, the analysis focuses on the different capitals (financial, manufactured, intellectual, human, social and relationship, and natural) under the IIRC Framework. Considering that the terminology the sampled firms adopted may vary (i.e., the same concept could be termed in different ways), a list of items concerning each capital, to be found in the text, was identified (Beattie, McInnes, \& Fearnley, 2004), with the aim of making the analysis replicable. The list of items was codified (unit of analysis) (Beattie \& Thomson, 2007) in accordance with the IIRC's definition of capitals, and two coders collected data separately. After a pilot test based on 25 observations (five firms observed over five years), a discussion was conducted among the authors to settle any discrepancies. The same coders continued the analysis separately, and a second discussion was conducted to examine and resolve any residual doubts. Table 2 shows the items searched in IRs.

Table 2. Items for capital definition

\begin{tabular}{ll}
\hline Category & Items (units of analysis) \\
\hline Financial Capital & Financial, Equity \\
Manufactured Capital & Manufactured, Buildings, Equipment, Infrastructure, Industrial \\
Intellectual Capital & Intellectual, Organizational, Intellectual Property \\
Human Capital & Human, Employee(s), Staff \\
Social and Relationship Capital & Social, Institutions, Communities, Brand and Reputation, Relational, Relationship \\
Natural Capital & Natural, Environmental \\
\hline
\end{tabular}


In the second step, for each capital, a score was assigned based on specific parameters (units of measurement) regarding the quantity and quality of the information found in the IR concerning the six capitals. More specifically:

- Score "1" if the IR does not provide any information regarding a specific capital, or if it simply labels the capital in a diagram without providing any comments or explanations.

- Score "2" if the IR mentions a specific capital, but provides only a very concise explanation (i.e., a short sentence) regarding its content and the link with the other capitals.

- Score " 3 " if the IR describes a capital in depth, dedicating a specific section of the report to it, in which qualitative information is provided and/or a connection with other capitals or with the value creation process is illustrated.

Therefore, the results from content analysis show how banks disclose this information (RQ1). In the third step, a correlation analysis was conducted to investigate whether a relationship exists between the disclosure of different capitals (RQ2) to avoid stakeholders needing to search for this information in separate and disconnected documents. Based on results that emerged from the content analysis, a principal component analysis (PCA) was performed. PCA, a dimensionality-reduction algorithm, is a statistical procedure that uses an orthogonal transformation to convert a set of observations of possibly correlated variables into a set of values of linearly uncorrelated variables called principal components (Jolliffe, 1986). PCA allows for summarization of multiple inter-correlated variables as a set of a few new variables. Furthermore, with PCA results, two weighted indices were built and used as dependent variables for two regression analyses that aimed to discover relationships among variables (Draper \& Smith, 1998), at the same time, unveiling if some determinants (profitability and firm size) affect disclosure levels (Kleinbaum et al., 1988).

\section{Findings}

\subsection{Descriptive Statistics}

Table 3 shows how many capitals are represented in IRs. During this step, the data were considered only if information regarding each capital was provided, regardless of its content (namely its quality). The "Capitals" column in Table 3 shows how many capitals are represented in IRs, then the absolute value and percentage value of IRs are highlighted.

Table 3. Capitals represented in IRs

\begin{tabular}{lll}
\hline Capitals represented in IRs & No. of IRs & \% of IRs \\
\hline 0 & 3 & $1 \%$ \\
1 & 28 & $13 \%$ \\
2 & 30 & $13 \%$ \\
3 & 14 & $6 \%$ \\
4 & 46 & $21 \%$ \\
5 & 22 & $10 \%$ \\
6 & 80 & $36 \%$ \\
Total & $\mathbf{2 2 3}$ & $\mathbf{1 0 0 \%}$ \\
\hline
\end{tabular}

The results illustrate that only three IRs (1\%) have not adopted the IIRC Framework's categories and are not structured along the lines of the capitals. It is worth noting that in $36 \%$ of the investigated IRs, all six capitals were represented, providing at least concise information on them. Between these two extremes, 28 IRs (13\%) described just one capital, namely the financial one, while $30(13 \%)$ mentioned two, namely the financial one and human capital (90\%), or social and relationship (10\%). 14 IRs (6\%) described three capitals, while $46(21 \%)$ described four. Finally, five capitals were present in 22 IRs (10\%).

Therefore, the analysis revealed that these firms are disclosing both financial and non-financial information. The process of integrated thinking is still evolving. In fact, only $36 \%$ of IRs disclosed all six capitals. Considering the focus on the financial sector, the results are far below expectations. This evidence is the first step toward answering the first RQ. For a deeper analysis, the data are unpacked year by year from 2014 to 2018 . Figure 1 shows the results. 


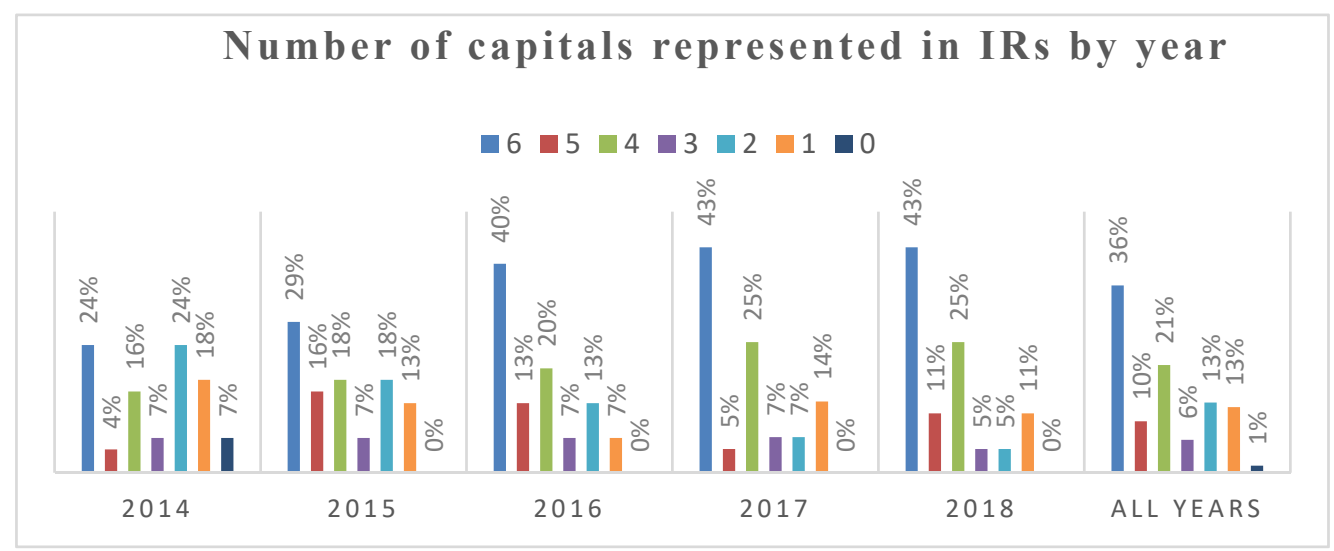

Figure 1. Number of capitals represented in IRs by year

As mentioned, several IRs included all six capitals, as highlighted by the blue lines in Figure 1. Furthermore, an increasing trend from 2104 to 2017 can be observed.

It is quite surprising that the percentage of IRs that describes five capitals is low, fluctuating from $4 \%$ in 2014 to $11 \%$ in 2018 . A clearer strengthening trend can be seen concerning the number of IRs that provide information regarding four capitals. The percentage of IRs that deal with four capitals increases during the years from 2014 $(16 \%)$ to $2018(25 \%)$.

The percentage of IRs dealing with three capitals is very low in all the considered years. A constant percentage of 7\% was found from 2014 to 2017 , and in 2018, the percentage decreased to $5 \%$.

The IRs that described two capitals showed a decreasing trend. In 2014, there was a considerable percentage (24\%), fell in 2015 (18\%), then decreasing sharply over time (13\% in 2016; 7\% in 2017; 5\% in 2018).

Few IRs dealt with one capital, with percentages fluctuating (18\% in $2014,13 \%$ in $2015,7 \%$ in $2016,14 \%$ in 2017 , and $11 \%$ in 2018).

In the end, only in 2014, there is a small percentage (7\%) considering no one capital.

Table 4 provides descriptive statistics on six capitals, illustrating mean, median, and standard deviation for financial, manufactured, intellectual, social and relationship, human, and natural capitals. Bearing in mind that the scores of the capitals range between 1 and 3 , financial capital always has a median of 3 . The mean value also appears to be near 3 . The standard deviation is slightly higher in $2014(0,53)$, but for the other years, the deviation from the mean value is very low, showing homogeneous results.

Manufactured capital presents a different scenario. The median was 1 , the minimum value. The mean remained low, even though it grew slightly over the years. Considering the score, the standard deviation was high each year.

More attention was paid to intellectual capital. In fact, with the exception of 2014 presenting a median value of 1 , the median always was equal to 2 during the other years. The mean was 1.47 in 2014, 1.71 in 2015, 1.96 in 2016, 1.89 in 2017, and 1.93 in 2018. This value grew until 2016, as values neared 2. However, also in this case, as in manufactured capital, the standard deviation presented noteworthy values. 
Table 4. Descriptive statistics of capitals

\begin{tabular}{|c|c|c|c|c|c|c|c|c|c|}
\hline & Mean & Median & SD & Mean & Median & SD & Mean & Median & SD \\
\hline & \multicolumn{3}{|c|}{ Financial capital } & \multicolumn{3}{|c|}{ Manufactured capital } & \multicolumn{3}{|c|}{ Intellectual capital } \\
\hline 2014 & 2.82 & 3.00 & 0.53 & 1.40 & 1.00 & 0.72 & 1.47 & 1.00 & 0.73 \\
\hline 2015 & 2.98 & 3.00 & 0.15 & 1.58 & 1.00 & 0.81 & 1.71 & 2.00 & 0.79 \\
\hline 2016 & 2.96 & 3.00 & 0.21 & 1.62 & 1.00 & 0.81 & 1.96 & 2.00 & 0.80 \\
\hline 2017 & 2.95 & 3.00 & 0.21 & 1.66 & 1.00 & 0.81 & 1.89 & 2.00 & 0.78 \\
\hline 2018 & 2.95 & 3.00 & 0.21 & 1.66 & 1.00 & 0.81 & 1.93 & 2.00 & 0.76 \\
\hline year & \multicolumn{3}{|c|}{ Social/Relationship capital } & \multicolumn{3}{|c|}{ Human capital } & \multicolumn{3}{|c|}{ Natural capital } \\
\hline 2014 & 1.76 & 2.00 & 0.77 & 2.02 & 2.00 & 0.84 & 1.56 & 1.00 & 0.72 \\
\hline 2015 & 1.89 & 2.00 & 0.78 & 2.22 & 2.00 & 0.77 & 1.80 & 2.00 & 0.79 \\
\hline 2016 & 2.13 & 2.00 & 0.76 & 2.40 & 3.00 & 0.72 & 1.96 & 2.00 & 0.80 \\
\hline 2017 & 2.00 & 2.00 & 0.75 & 2.36 & 3.00 & 0.75 & 1.93 & 2.00 & 0.82 \\
\hline 2018 & 2.11 & 2.00 & 0.65 & 2.41 & 3.00 & 0.73 & 1.93 & 2.00 & 0.79 \\
\hline
\end{tabular}

As for social and relational capital, the median was 2 for all five years. The mean was 1.76 in 2014, 1.89 in 2015, 2.13 in 2016, 2.00 in 2017, and 2.11 in 2018. As with intellectual capital, with the social and relationship, a peak was reached in 2016, after which there was a very small decline (in 2017). It is important to note how far the values were from the mean, which was given by the standard deviation. These values were 0.77 in $2014,0.78$ in 2015, 0.76 in 2016, 0.75 in 2017, and 0.65 in 2018.

Regarding human capital, the median values were 2 for the years 2014 and 2015, then at a maximum value (3) for 2016, 2017, and 2018. In fact, the average values always were above 2. Specifically, the values were 2.02 in 2014, 2.22 in 2015, 2.40 in 2016, 2.36 in 2017, and 2.41 in 2018. As for intellectual capital and social and relationship capital, a peak was reached in 2016, but in this case, another peak occurred in 2018. However, even here, the standard deviation values were not low, at 0.84 in 2014, 0.77 in 2015, 0.72 in 2016, 0.75 in 2017, and 0.73 in 2018 .

To summarize, natural capital's values were closer to those of intellectual capital. The median value was 1 in 2014, but 2 for the other years. The mean was 1.56 in 2014, 1.80 in 2015, 1.96 in 2016, 1.93 in 2017, and 1.93 in 2018. These values grew until 2016. Also in this case, as noted for intellectual capital, social and relationship, and human, as far as mean values, there was a maximum in 2016. The standard deviation presented consistent values.

Bearing in mind the first research question, with these results, it is possible to understand how banks disclose information on financial and non-financial capital in their IRs. In particular, the IRs still are rooted mainly in financial information, providing detailed data both in quantity and quality senses. The attention paid to non-financial capital types remained weak and is not satisfactory. However, over time, the disclosure level has been increasing, especially concerning human capital, followed by social and relationship capital. Quite surprisingly, the disclosure level concerning intellectual capital is low, despite it being one of the capitals investigated most often in the literature.

\subsection{Analysis of Correlations between Capitals}

To discover the association between variables, a correlation analysis was performed. Table 5 shows the results.

Table 5. Correlation matrix

\begin{tabular}{|c|c|c|c|c|c|c|}
\hline & Financial & Manufactured & Intellectual & $\begin{array}{l}\text { Social \& } \\
\text { Relationship } \\
\end{array}$ & Human & Natural \\
\hline Financial & 1 & & & & & \\
\hline Intellectual & .131 & $.780 * *$ & 1 & & & \\
\hline Social \& Relationship & .113 & $.662 * *$ & $.794 * *$ & 1 & & \\
\hline Natural & .048 & $.733 * *$ & $.618 * *$ & $.670 * *$ & $.485 * *$ & 1 \\
\hline
\end{tabular}

Note. ${ }^{*}{ }^{* *}$ The correlation is statistically significant at the 0.05 and 0.01 levels, respectively (two-tailed). 
Table 5 shows that financial capital was correlated with no other capital. The other capitals - manufactured, intellectual, social and relationship, human, and natural - presented a statistically significant correlation among them. In particular, higher positive values can be observed between manufactured, intellectual, social and relationship, and natural. This indicates a positive relationship among disclosures concerning these four capitals. Human capital always was correlated positively with manufactured, intellectual, social and relationship, and natural, but its value was lower than those concerning the relationship between other capitals. The correlation analysis highlights the clear separation between financial and non-financial capitals.

To achieve a more in-depth understanding of the phenomena investigated, and to identify the relationship between disclosures concerning the different capitals better, a principal component analysis (PCA) was conducted. This kind of analysis could be interpreted as a first attempt to assess the connectivity between capitals by examining the connections between their disclosure levels.

The PCA reduces the data set's dimensionality through the extraction of a defined number of principal components, summarizing the observed data. According to the current literature (Jolliffe, 2002; Di Franco \& Marradi, 2003), the first $k$ factors with an eigenvalue greater than 1 were extracted.

Table 6 shows the two extracted principal components' scores (PCs).

Table 6. Principal component analysis

\begin{tabular}{lll}
\hline Capitals & PC1 & PC2 \\
\hline Financial & 0.169 & 0.971 \\
Manufactured & 0.875 & -0.120 \\
Intellectual & 0.897 & -0.018 \\
Social \& Relationship & 0.879 & -0.030 \\
Human & 0.712 & 0.149 \\
Natural & 0.832 & -0.147 \\
\hline
\end{tabular}

Two components were extracted. The results from principal components clearly show that the first PC presented the highest factor loadings for manufactured, intellectual, social and relationship, human, and natural capitals. These values were all close to 0.8 or higher. Accordingly, these different factors can be summarized in one variable labeled "non-financial information." The second PC shows the relevance of financial capital, exclusively, with the other items' values being close to zero or even negative.

Therefore, according to these results, it is possible to answer the second research question. In IRs, no relation exists yet between disclosure of financial and non-financial information. Instead, the results document a strong separation between financial and non-financial information. This lack of a relationship could be interpreted as a sign of low connectivity among capitals, despite their critical and important role in the IIRC Framework (Incollingo \& Bianchi, 2016).

\subsection{Regression Model}

To understand whether specific factors could explain each firm's disclosure levels regarding the six capitals, a regression analysis was conducted. Considering that the sample comprises panel data showing a combination of the time series and cross-sectional design, a Hausman test was applied preliminarily to check for the appropriate model between the fixed effect and random effect models. Retaining the PCA results as a starting point, two indices were created by using the two extracted components' eigenvalues. The construction of these indices was based on two steps. First, the score that expresses the disclosure level attributed to each capital was multiplied by the coefficient regarding the same capital, as expressed in Table 6. Second, the sum of all weighted capitals' values was used to obtain a specific index. Considering that two components have been extracted, two indices, $\mathrm{ID}_{1}$ and $\mathrm{ID}_{2}$, have been obtained, which rely on results concerning the first and second extracted components, respectively.

The formula for indices $\mathrm{ID}_{1}$ and $\mathrm{ID}_{2}$ was developed as follows:

$$
I D_{1}=\sum_{i=1}^{y}\left(d_{i} * P C 1_{i}\right)
$$




$$
I D_{2}=\sum_{i=1}^{y}\left(d_{i} * P C 2_{i}\right)
$$

in which $y=6$ (IIRC capitals); $d i \in\{1,2,3\}=$ capital score; PC1= first extracted component by PCA; PC2= second extracted component by PCA.

These two indices are viewed as dependent variables in the regression analysis, which aims to understand whether a relationship exists between the weighted index concerning the six capitals and the sampled firms' profitability and size. The underlying assumption is that the bigger the size and the more profitable the firm, the higher the disclosure level (Inchausti, 1997; Ajide \& Aderemi, 2014).

Size is expressed through two parameters:

- Total assets (TotAss $\mathrm{it}_{\mathrm{i}}$ ), expressed as the natural logarithm of total assets at year $t$. Taking into account that the currency adopted by the sampled firms is different, all the values were converted to euros using the rate on January 1 of each year examined in the study (expected sign: + ).

- Number of employees (EMP it $_{\text {) }}$ (expected sign: + ).

Profitability is expressed through the return on equity (ROE) ratio (expected sign: + ).

In addition, the model includes the following control variables:

- Geographical area (Geo), represented by a nominal variable that takes these values: Africa $=1$; North and South America $=2 ;$ Asia $=3$; Europe $=4$; and Oceania $=5$. This variable has been included in the model, as the country's stakeholder orientation could influence disclosure levels (Dhaliwal, Li, Tsang, \& Yang, 2014; Ernstberger \& Grüning, 2013).

- Gross domestic product per capita $\left(\mathrm{GDP}_{\mathrm{it}}\right)$ is the gross domestic product divided by population and calculated annually as a proxy for economic development (Vaz, Fernandez-Feijoo, \& Ruiz, 2016).

For panel data, the fixed - or random - effects estimators could be used to estimate the $\beta$ parameters. Therefore, to choose the appropriate model, a Hausman test was performed, and the results (not tabulated here) suggest adopting a fixed effects model, the assumptions of which indicate that the Geo variable can be omitted, as it is time-invariant. This model controls the unobserved, constant heterogeneity problem in the data; therefore, the following equations show the variables included in the model:

$$
\begin{aligned}
& I D_{1 \mathrm{it}}=\beta_{\mathrm{it}}+\beta_{1} \text { TotAss }_{\mathrm{it}}+\beta_{2} \mathrm{EMP}_{\mathrm{it}}+\beta_{3} \mathrm{ROE}_{\mathrm{it}}+\beta_{4} \mathrm{GDP}_{\mathrm{it}}+\varepsilon_{i t} \\
& I D_{2 i t}=\beta_{i t}+\beta_{1} \text { TotAss }_{i t}+\beta_{2} E M P_{i t}+\beta_{3} \mathrm{ROE}_{i t}+\beta_{4} G D P_{i t}+\varepsilon_{i t}
\end{aligned}
$$

in which $I D_{1 \text { it }}$ is the global weighted disclosure index calculated for each firm $(i)$ for each year $(t)$ using PCA results from the first extracted component. $I D_{2}$ it is the global weighted disclosure index calculated for each firm $(i)$, each year $(t)$, from PCA results on the second extracted component. The $\beta$ parameters are to be estimated, but invariant over time, while $\varepsilon_{i t}$ is the error term.

Preliminary, bivariate correlations among all independent variables have been calculated. According to the results, as illustrated in Table 7, correlation is not an issue, and all variables can be entered into the models. In fact, the results show that no multicollinearity issues exist.

Table 7. Correlation matrix independent variables

\begin{tabular}{llllll}
\hline & ROE & Total Assets & Employees & Geo & GDP \\
\hline ROE & 1 & & & & \\
Total Assets & .013 & 1 & & & \\
Employees & $-.141^{*}$ & -0.132 & 1 & & \\
Geo & $-.152^{*}$ & $.186^{* *}$ & $-.243^{* *}$ & 1 & \\
GDP & -0.091 & $.325^{* *}$ & 0.037 & -0.058 & 1 \\
\hline
\end{tabular}

Note. $*, * *$ The correlation is statistically significant at the 0.05 and 0.01 levels, respectively (two-tailed) 
Table 8. Regression results

\begin{tabular}{lllllll}
\hline \multicolumn{2}{l}{ Model 1 (dependent variable: ID $_{\mathbf{1}}$ ) } & \multicolumn{5}{l}{ Model 2 (dependent variable: $\mathbf{I D}_{\mathbf{2}}$ ) } \\
\hline & B & Std. Err. & Sign. & B & Std. Err. & Sign. \\
\hline (Constant) & 5.202 & 0.781 & 0.000 & 2.613 & 0.157 & 0.000 \\
ROE & -0.006 & 0.029 & 0.851 & 0.010 & 0.006 & 0.093 \\
Total Assets & $5.728 \mathrm{E}-08$ & $3.639 \mathrm{E}-08$ & 0.117 & $8.218 \mathrm{E}-09$ & $7.315 \mathrm{E}-09$ & 0.263 \\
EMP & $6.772 \mathrm{E}-07$ & $1.156 \mathrm{E}-05$ & 0.953 & $3.781 \mathrm{E}-07$ & $2.324 \mathrm{E}-06$ & 0.871 \\
GDP & $1.784 \mathrm{E}-05$ & $3.859 \mathrm{E}-06$ & 0.000 & $2.332 \mathrm{E}-06$ & $7.758 \mathrm{E}-07$ & 0.003 \\
$R^{2}$ & .735 & & & .470 & & \\
Adj $R^{2}$ & .661 & & & .322 & & \\
$F$ & 9.915 & & & 3.172 & & \\
Prob $>F$ & 0.000 & & & 0.000 & & \\
\hline
\end{tabular}

Table 8 provides the results from the regression model to test Equations 1 and 2. Model 1, with ID1 as the dependent variable, is statistically significant (P-value $<0.001$ ); furthermore, the model explains a large portion of the total variance from the phenomenon investigated, with $\mathrm{R}^{2}$ and $\mathrm{R}^{2}$ adjusted being 0.735 and 0.661 , respectively.

The results show that GDP is statistically significant at the $1 \%$ level and influences the model positively. The other variables (ROE, total assets, EMP) are not statistically significant, but it is interesting to note the ROE coefficient's negative sign, although the coefficient's value is close to zero. Therefore, when disclosure on non-financial information (ID1) increases, ROE decreases.

Model 2, with ID2 as the dependent variable, is statistically significant (P-value $<0.001$ ), and the $\mathrm{R}^{2}$ and $\mathrm{R}^{2}$-adjusted values are 0.470 and 0.322 , respectively. Also in this case, as with Model 1, GDP is statistically significant at the level of $1 \%$ and presents a positive coefficient. Also, ROE is statistically significant at the $1 \%$ level, with a positive impact. The variables of total assets and number of employees are not statistically significant.

Therefore, in both models, the country's economic development, as shown through GDP, positively influences disclosure levels for both financial and non-financial information. Furthermore, regarding financial information, the higher the profitability level, the higher the disclosure level concerning financial capital. However, this factor does not affect non-financial information.

\section{Discussion and Conclusion}

The paper aimed to assess disclosure quality concerning both financial and non-financial capitals within banks' integrated reports (IRs). In particular, the study investigated how banks disclose information concerning the six capitals in their IRs and the eventual relationship between disclosure of financial and non-financial information. Only in this way is it possible to understand the value creation process through IRs, considering that capitals are stocks of value that are increased, decreased, or transformed through an organization's activities and outputs (IIRC, 2013, para. 2.11). Value creation, as well as the connection between different capitals led by integrated thinking, is the distinctive core of the IR, compared with other forms of reports, such as sustainability reports or corporate social responsibility reports.

Furthermore, the analysis focuses on the banking sector and considers their fundamental role in the economic system and their activity's strong social impact on the country. Therefore, a large sample of firms belonging to the financial industry was investigated by scrutinizing 223 IRs over five years (from 2014 to 2018). More specifically, it has been examined how firms provide information concerning the six capitals identified by the IIRC Framework, which means considering the resources used and affected by an organization during its value-creation process.

From a methodological perspective, different steps were carried out. Through a content analysis methodology, a label showing the quantity and quality of information was provided, expanding non-financial information in the integrated reports and improving disclosure of capitals other than the financial kind. Generally, it has been found that the disclosure level concerning these capitals has increased over time, particularly from 2014 to 2016 . From 2016 onward, the situation was fairly stationary. In the years, there was a strong focus on financial capital, then major attention was paid to non-financial capitals, especially human capital. The least-investigated capital was manufactured. The results show that the banks pay attention to financial data (defined financial capital) in a principal way, but the results from non-financial information were not satisfactory. The IIRC $(2013 ;$ p.7) 
establishes that "the primary purpose of an integrated report is to explain to providers of financial capital how an organization creates value over time. It, therefore, contains relevant information, both financial and other." After seven years, this process remains ongoing, and it is impossible to state that IRs contain complete information. The results bring to light the limits of the framework debated in the literature.

Considering the relationship between disclosure of financial and non-financial capitals, the results indicate a clear distinction between financial capital on one side and non-financial capitals on the other side. A relationship exists among all non-financial capitals, but none exists between them and the financial capital. These results represent the first phase of integrated thinking, leading to better integration of information systems and the right way to pursue "connectivity and interdependencies between the range of factors that affect an organization's ability to create value over time" (IIRC, p.2). We are aware that these results do not provide evidence of connectivity between capitals, but could represent the first "indirect" measurement method to be expanded for further research.

Finally, the paper investigated whether some dimensional and economic factors could influence disclosure levels. Dimensional factors consider "total assets" and "number of employees," while economic factors analyze the "profitability" of sampled firms expressed through the return-on-equity ratio. Furthermore, other variables have been tested, such as "gross domestic product per capita," as a proxy for economic development. Findings that emerged from the analysis highlight that both profitability and size do not influence the disclosure of non-financial capitals, while profitability is relevant concerning disclosure of financial capital. Furthermore, in all cases, economic development within the country in which the companies belong - measured by gross domestic product per capita - positively impacts information in IRs.

This study contributes to the academic debate on the use of IR in practice, providing useful insights regarding the disclosure of resources used and affected by an organization and their role in value creation over time. This research also could support better comprehension of how IR is implemented in practice, unveiling the reasons that could motivate banks to provide more (or no) detailed information regarding their "critical" capitals. This study's findings also could benefit practitioners. Information conveyed by IRs needs to be interpreted in light of the strategic approach that firms adopted. The results indicate that in the banking sector, there is a lack of integrated thinking that is an integral element in producing the document and will "help catalyze behavioral change within organizations" (Adams \& Simnett, 2011). Strong roots in financial information still exist, and not all banks' IRs are developed according to the logic of capital, demonstrating that the IIRC's forms of capital exert little impact on corporate reporting practices because of their lack of force (Flower, 2015). In fact, the six capitals are not all equally relevant, and financial capital remains pivotal. It still seems that value creation is geared toward the main stakeholder, which is the investor. Therefore, the concept of value is still inclined toward a specific stakeholder category, calling attention to "value for investors," not "value for society" (Flower, 2015). However, some signs of improvement were noted regarding the disclosure of human capital, but it is not enough. The banking firms demonstrated difficulty in taking a holistic approach in constructing an integrated report. Given these considerations, is it possible to consider integrated thinking in the report? Perhaps the IR still represents a form of reporting that is particularly ambitious, as its concrete implementation requires advanced technical skills, but above all, a holistic vision of business processes and companies' social roles remains slow in establishing itself.

In conclusion, even though this study has considered sampled firms' geographical locations, a more in-depth analysis concerning specific countries could improve our understanding concerning the IR's role in different contexts. Indeed, the literature on international accounting has long emphasized how relevant contextual factors' role can be, along with accounting traditions and culture, to financial reporting's characteristics. Therefore, future studies could investigate these issues.

\section{References}

Abeysekera, I. (2013). A template for integrated reporting. Journal of Intellectual Capital, 14(2), 227-245. https://doi.org/10.1108/14691931311323869

Abhayawansa, S., \& Guthrie, J. (2010). Intellectual capital and the capital market: a review and synthesis. Journal of Human Resource Costingx and Accounting, 14(3), 196-226. https://doi.org/10.1108/14013381011095472

Adams, C. A. (2015). The International Integrated Reporting Council: A call to action. Critical Perspectives on Accounting, 27, 23-28. https://doi.org/10.1016/j.cpa.2014.07.001

Adams, C. A. (2017). The Sustainable Development Goals, integrated thinking and the Integrated report. 
Retrieved from http://integratedreporting.org/resource/sdgs-integrated-thinking-and-the-integrated-report/

Adams, C. A., \& Simnett, R. (2011). Integrated Reporting: An opportunity for Australia's not-for-profit sector. Australian Accounting Review, 21(3), 292-301. https://doi.org/10.1111/j.1835-2561.2011.00143.x

Adams, C. A., Potter, B., Singh, P. J., \& York, J. (2016). Exploring the implications of integrated reporting for social investment (disclosures). The British Accounting Review, 48, 283-296. https://doi.org/10.1016/j.bar.2016.05.002

Ahmed Haji, A., \& Anifowose, M. (2017). Initial trends in corporate disclosures following the introduction of integrated reporting practice in South Africa. Journal of Intellectual Capital, 18(2), 373-399. https://doi.org/10.1108/JIC-01-2016-0020

Ajide, F. M., \& Aderemi, A. A. (2014). The effects of corporate social responsibility activity disclosure on corporate profitability: Empirical evidence from Nigerian commercial banks. IOSR Journal of Economics and Finance (IOSRJEF), 2(6), 17-25.

Ambec, S., \& Lanoie, P. (2008). Does it pay to be green? A systematic overview. Academy of Manage Perspectives, 22(4), 45-62. https://doi.org/10.5465/amp.2008.35590353

Arvidsson, S. (2011). Disclosure of non-financial information in the annual report: A management-team perspective. Journal of intellectual capital, 12(2), 277-300. https://doi.org/10.1108/14691931111123421

Barometer, Edelman Trust (2019). Edelman trust barometer global report. Edelman. Retrieved from https://www.edelman.com/sites/g/files/aatuss191/files/2019-02/2019_Edelman_Trust_Barometer_Global Re port_2.pdf

Barth, M. E., Cahan, S. F., Chen, L., \& Venter, E. R. (2017). The Economic Consequences Associated with Integrated Report Quality: Capital Market and Real Effects. Accounting, Organizations and Society, 62, 43-64. https://doi.org/10.1016/j.aos.2017.08.005

Beattie, V., \& Thomson, S. J. (2007). Lifting the lid on the use of content analysis to investigate intellectual capital disclosures. Accounting forum, 31(2), 129-163. https://doi.org/10.1016/j.accfor.2007.02.001

Beattie, V., McInnes, B., \& Fearnley, S. (2004). A methodology for analyzing and evaluating narratives in annual reports: A comprehensive descriptive profile and metrics for disclosure quality attributes. Accounting Forum, 28(3), 205-236. http://dx.doi.org/10.1016/j.accfor.2004.07.001

Beck, C., Dumay, J., \& Frost, G. (2017). In pursuit of a 'single source of truth': from threatened legitimacy to integrated reporting. Journal of Business Ethics, 141(1), 191-205. https://doi.org/10.1007/s10551-014-2423-1

Brown, J., \& Dillard, J. (2014). Integrated reporting: On the need for broadening out and opening up. Accounting, Auditing and Accountability Journal, 27(7), 1120-1156. https://doi.org/10.1108/AAAJ-04-2013-1313

Buckley, R. P., \& Arner, D. W. (2011). From Crisis to Crisis. The Global Financial System and Regulatory Failure. Kluwer Law International, University of Hong Kong, Faculty of Law.

Busco, C., Granà, F., \& Izzo, M. F. (2018). Sustainable development goals and integrated reporting. Torino, G. Giappichelli Editore.

Camilleri, M. A. (2017). The integrated reporting of financial, social and sustainability capitals: a critical review and appraisal. International Journal of Sustainable Society, 9(4), 311-326. https://doi.org/10.1504/IJSSOC.2017.090523

Camodeca, R., \& Almici, A. (2017). Implementing Integrated Reporting: Case Studies from the Italian Listed Companies. Accounting and Finance Research, 6(2), 121-135. https://doi.org/10.5430/afr.v6n2p121

Casonato, F., Farneti, F., \& Dumay, J. (2019). From Sustainability to Integrated Reporting: How the IIRC Framework Affected Disclosures by a Financial Institution in Australia. In S. O. Idowu, \& M. Del Baldo (Eds.), Integrated Reporting. Antecedents and Perspectives for Organizations and Stakeholders (pp. 125-140). Berlin, Springer.

Chen, Y. P., \& Perrin, S. (2017). Insights into Integrated Reporting: Challenges and Best Practice Responses. Association of Chartered Certified Accountants (ACCA), London.

Cheng, M., Green, W., Conradie, P., Konishi, N., \& Romi A. (2014). The International Integrated Reporting Framework: Key Issues and Future Research Opportunities. Journal of International Financial Management and Accounting, 25(1), 90-119. https://doi.org/10.1111/jifm.12015

Chersan, I. C. (2015). Study on Practices and Tendencies in Integrated Reporting. Audit Financiar, 13(129), 
91-101.

Comerio, N., \& Tettamanzi, P. (2019). Systematic literature network analysis in accounting: A first application on integrated reporting research. Financial reporting, 2, 73-109. https://doi.org/10.3280/FR2019-002004

Crotty, J. (2009). Structural causes of the global financial crisis: A critical assessment of the 'new financial architecture'. Cambridge Journal of Economics, 33(4), 563-580. https://doi.org/10.1093/cje/bep023

de Villiers, C., Rinaldi, L., \& Unerman, J. (2014). Integrated Reporting: Insights, gaps and an agenda for future research. Accounting, Auditing and Accountability Journal, 27(7), 1042-1067. https://doi.org/10.1108/AAAJ-06-2014-1736

de Villiers, C., Venter, E. R., \& Hsiao, P. K. (2017). Integrated Reporting: Background, Measurement Issues, Approaches and an Agenda for Future Research. Accounting and Finance, 57(4), 937-959. https://doi.org/10.1111/acfi.12246

Demirguc-Kunt, A., \& Levine, R. (2000). Bank concentration: cross-country evidence. In World Bank Global Policy Forum Working Paper.

Dhaliwal, D., Li, O. Z., Tsang, A., \& Yang, Y. G. (2014). Corporate social responsibility disclosure and the cost of equity capital: the roles of stakeholder orientation and financial transparency. Journal of Accounting and Public Policy, 33(4), 328-355. https://doi.org/10.1016/j.jaccpubpol.2014.04.006

Di Franco, G., \& Marradi, A. (2003). Analisi fattoriale e analisi in componenti principali. Acireale (CT), Bonanno.

Draper, N. R., \& Smith, H. (1998). Applied regression analysis (Vol. 326). New York, John Wiley \& Sons.

Dumay, J., and Dai, T. (2017). Integrated thinking as a cultural control? Meditari Accountancy Research, 25(4), 574-604. https://doi.org/10.1108/MEDAR-07-2016-0067

Dumay, J., Bernardi, C., Guthrie, J., \& Demartini, P., (2016). Integrated Reporting: A structured literature review. Accounting Forum, 40, 166-185. https://doi.org/10.1016/j.accfor.2016.06.001

Dumay, J., Bernardi, C., Guthrie, J., \& La Torre, M., (2017). Barriers to implementing the International Integrated Reporting Framework: A contemporary academic perspective. Meditari Accountancy Research, 25(4), 461-480. https://doi.org/10.1108/MEDAR-05-2017-0150

Dumay, J., La Torre, M., \& Farneti F. (2019). Developing trust through stewardship: Implications for IC, Integrated Reporting, and the EU Directive 2014/95/EU, Journal of Intellectual Capital, 20, 11-39. https://doi.org/10.1108/JIC-06-2018-0097

Dwyer, R., Lamond, D., Molina-Azorín, J. F., Claver-Cortés, E., López-Gamero, M. D., \& Tarí, J. J. (2009). Green management and financial performance: a literature review. Management Decision, 467(7), 1080-1100. https://doi.org/10.1108/00251740910978313

Eccles, R. G. \& Kiron, D. (2012). Get ready: mandated integrated reporting is the future of corporate reporting. MIT Sloan Management Review, 53(3), 1-5.

Eccles, R. G., \& Krzus, M. P. (2010), One report - Integrated Reporting for a Sustainable Strategy. New Jersey, John Wiley and Sons.

Eccles, R. G., \& Saltzman, D. (2011). Achieving Sustainability Through Integrated Reporting. Stanford Social Innovation Review, 9(3), 56-61.

Eccles, R. G., Beiting, C., \& Saltzam, D. (2010). The Landscape of Integrated Reporting. Reflections and next steps. Boston, Harvard Business School.

Eccles, R. G., Krzus, M. P. \& Ribot, S. (2015). Models of best practice in integrated reporting 2015. Journal of Applied Corporate Finance, 27(2), 103-115. https://doi.org/10.1111/jacf.12123

Eccles, R. G., Krzus, M. P., \& Watson L.A. (2012). Integrated reporting requires Integrated Assurance. In J. Oringel (Ed.), Effective Auditing for Corporates: Key Developments in Practice and Procedures. London, Bloomsbury Information.

Eccles, R. G., Serafeim, G., \& Krzus, M. P. (2011). Market interest in nonfinancial information. Journal of Applied Corporate Finance, 23(4), 113-127. https://doi.org/10.1111/j.1745-6622.2011.00357.x

Elkington, J. (2009). The holy grail of integrated reporting. Retrieved from https://sustainability.com/our-work/insights/the-holy-grail-of-integrated-reporting/ 
Ernstberger, J., \& Grüning, M., (2013). How do firm- and country-level governance mechanisms affect firms' disclosure? Journal of Accounting and Public Policy, 32(32), 50-67. https://doi.org/10.1016/j.jaccpubpol.2013.02.003

European Parliament. (2014). Directive 2014/95/EU(2014).

EY. (2014). Integrated reporting: elevating value. Retrieved from http://www.ey.com/Publication/vwLUAssets/EY-Integrated-reporting/\$FILE/EY-Integrated-reporting.pdf

Feng, T., Cummings, L. \& Tweedie, D. (2017). Exploring integrated thinking in integrated reporting - an exploratory study in Australia. Journal of Intellectual Capital, 18(2), 330-353. https://doi.org/10.1108/JIC-06-2016-0068

Flower, J. (2015). The International Integrated Reporting Council: A story of failure. Critical Perspectives on Accounting, 27, 1-17. https://doi.org/10.1016/j.cpa.2014.07.002

Freeman, R. E. (1994). The politics of stakeholder theory: Some future directions. Business ethics quarterly, 4(4), 409-421. https://doi.org/10.2307/3857340

Frias-Aceituno, J. V., Rodriguez- Ariza, L., \& Garcia-Sanchez, I. M. (2013a). Is integrated reporting determined by a country's legal system? An exploratory study. Journal of Cleaner Production, 44, 45-55. https://doi.org/10.1016/j.jclepro.2012.12.006

Frias-Aceituno, J. V., Rodriguez-Ariza, L., \& Garcia-Sanchez, I. M. (2013b). The role of the board in the dissemination of integrated corporate social reporting. Corporate Social Responsibility and Environmental Management, 20(4), 219-233. https://doi.org/10.1002/csr.1294

Frías-Aceituno, J. V., Rodríguez-Ariza, L., \& Garcia-Sánchez, I. M. (2014). Explanatory factors of integrated sustainability and financial reporting. Business Strategy and the Environment, 23(1), 56-72. https://doi.org/10.1002/bse.1765

Garcia-Sanchez, I. M., Rodriguez-Ariza, L., \& Frias-Aceituno, J. V. (2013). The cultural system and integrated reporting. International Business Review, 22(5), 828-838. https://doi.org/10.1016/j.ibusrev.2013.01.007

Gibassier, D., Rodrigue, M., \& Arjaliès, D. L. (2017). Integrated Reporting Is Like God: No One Has Met Him, but Everybody Talks About Him. The Power of Myths in the Adoption of Management Innovations. Accounting, Auditing and Accountability Journal, Forthcoming, Retrieved from https://ssrn.com/abstract=2880144 https://doi.org/10.1108/AAAJ-07-2016-2631

Gray, R. (2006). Social, environmental and sustainability reporting and organisational value creation? Whose value? Whose creation? Accounting, Auditing and Accountability Journal, 19 (6), 793-819. https://doi.org/10.1108/09513570610709872

Helleiner, E. (2011). Understanding the 2007-2008 global financial crisis: Lessons for scholars of International Political Economy. Annual Review of Political Science, 14, 67-87. https://doi.org/10.1146/annurev-polisci-050409-112539

Higgins, C., Stubbs, W., \& Love, T. (2014). Walking the talk(s): Organisational narratives of integrated reporting. Accounting, Auditing and Accountability Journal, 27(7), 1090-1119. https://doi.org/10.1108/AAAJ-04-2013-1303

Holsti, O. R. (1969). Content Analysis for the Social Sciences and Humanities (ed.). Reading, Addison-Wesley Boston.

IIRC. (2011). Towards Integrated Reporting. Communicating value in the 21th Century. Discussion Paper Retrieved from www. integratedreporting.org/resource/ discussion-paper/

IIRC. (2013). International Integrated Reporting Framework. Retrieved from http://www.integratedreporting.org/resource/international-ir-framework/

IIRC. (2015). Banking Network, Applying the Integrated Reporting concept of 'capitals' in the banking industry. Retrieved from http://www.integratedreporting.org/resource/ir-banking-network/

Inchausti, B. G. (1997). The Influence of Company Characteristics and Accounting Regulations on Information Disclosed by Spanish Firms. The European Accounting Review, 1(1), 45-68. https://doi.org/10.1080/096381897336863

Incollingo, A. (2014). Le prime esperienze di bilancio integrato. Analisi e riflessioni (1st ed.). Torino, Giappichelli. 
Incollingo, A., \& Bianchi, M. (2016). The Connectivity of Information in Integrated Reporting. Empirical Evidence from International Context. Financial Reporting, 2, 55-79. https://doi.org/10.3280/FR2016-002003

Jensen, J. C., \& Berg, N. (2012). Determinants of Traditional Sustainability Reporting Versus Integrated reporting. An Institutionalist Approach. Business Strategy and the Environment, 21(5), 299-316. https://doi.org/10.1002/bse.740

Jolliffe, I. T. (1986). Principal components in regression analysis In Principal component analysis. New York, NY Springer. (pp. 129-155). https://doi.org/10.1007/978-1-4757-1904-8_8

Jolliffe, I. T. (2002). Principal components in regression analysis. Principal component analysis. New York, NY Springer. (pp.167-198)- https://doi.org/10.1007/0-387-22440-8_8

Kleinbaum, D. G., Kupper, L. L., Muller, K. E., \& Nizam, A. (1988). Applied regression analysis and other multivariable methods. Duxbury Press, Belmont, CA.

KPMG. (2012). Integrated reporting in practice: The South African story.

Krippendorff K. (2013). Content Analysis. An Introduction to Its Methodology. SAGE, Inc.: Thousand Oaks, CA, USA.

Lee, K. W., \& Yeo, G. H. H. (2016). The association between integrated reporting and firm valuation. Review of Quantitative Finance and Accounting, 47(4), 1221-1250. https://doi.org/10.1007/s11156-015-0536-y

Manes-Rossi, F. (2018). Is integrated reporting a new challenge for public sector entities? African Journal of Business Management, 12(7), 172-187. https://doi.org/10.5897/AJBM2018.8498

Marx, B., \& Mohammadali-Haji, A. (2014). Emerging trends in reporting: an analysis of integrated reporting practices by South African top 40 listed companies. Journal of Economic and Financial Sciences, 7(1), $231-250$

McGuire, J. B., Schneeweis, T., \& Branch, B. (1990). Perceptions of firm quality: A cause or result of firm performance. Journal of management, 16(1), 167-180. https://doi.org/10.1177\%2F014920639001600112

Melloni, G. (2015). Intellectual capital disclosure in integrated reporting: An impression management analysis. Journal of Intellectual Capital, 16(3), 661-680. https://doi.org/10.1108/JIC-11-2014-0121

Melloni, G., Caglio, A., \& Perego, P. (2017). Saying More with Less? Disclosure Conciseness, Completeness and Balance in Integrated Reports. Journal of Accounting and Public Policy, 36(3), 220-238. https://doi.org/10.1016/j.jaccpubpol.2017.03.001

Miles, M. P., \& Covin, J. G. (2000). Environmental marketing: a source of reputational, competitive and financial advantage. Journal of Business Ethics, 23(3), 299-311. https://doi.org/10.1023/A:1006214509281

Milne, M., \& Gray, R. (2013). W(h)ither Ecology? The Triple Bottom Line, the Global Reporting Initiative, and Corporate Sustainability Reporting. Journal of Business Ethics, 118(1), 13-29. https://doi.org/10.1007/s10551-012-1543-8

Mio, C., Fasan, M., \& Pauluzzo, R. (2016). Internal application of IR principles: Generali's Internal Integrated Reporting. Journal of Cleaner Production, 139, 204-2018. https://doi.org/10.1016/j.jclepro.2016.07.149

Muserra, A. L., Papa, M., \& Grimaldi, F. (2020). Sustainable development and the European Union Policy on non-financial information: An Italian empirical analysis. Corporate Social Responsibility and Environmental Management, 27(1), 22-31. https://doi.org/10.1002/csr.1770

Nisha, N. (2016). Global financial crisis: exploring the special role of US banks and regulations. International Journal of Banking Risk \& Insurance, 4(1), 53-63.

Owen, G. (2013). Integrated Reporting: A review of Developments and their Implications for the Accounting Curriculum. Accounting Education: An International Journal, 22(4), 340-356. https://doi.org/10.1080/09639284.2013.817798

Perego, P., Kennedy, S., \& Whiteman, G. (2016). A lot of icing but little cake? Taking integrated reporting forward. Journal of Cleaner Production, 136, 53-64. https://doi.org/10.1016/j.jclepro.2016.01.106

PwC (2015). Integrated reporting Where to next? Retrieved from http://www.pwc.co.za/en/assets/pdf/integrated-reporting-survey-2015.pdf

Rinaldi L., Unerman, J., \& De Villiers, C. (2018). Evaluating the integrated reporting journey: insights, gaps and agendas for future research. Accounting, Audit and Accountability Journal, 31(5), 1294-1318. 
https://doi.org/10.1108/AAAJ-04-2018-3446

Romolini, A., Fissi, S., \& Gori, E., (2017). Exploring Integrated Reporting Research: Results and Perspectives. International Journal of Accounting and Financial Reporting, 7(1), 32-59. http://dx.doi.org/10.5296/ijafr.v7i1.10630

Ruiz-Lozano, M., \& Tirado-Valencia, P. (2016). Do industrial companies respond to the guiding principles of the Integrated Reporting framework? A preliminary study on the first companies joined to the initiative. Revista de Contabilidad - Spanish Accounting Review, 19(2), 252-260. https://doi.org/10.1016/j.rcsar.2016.02.001

Santis, S., Bianchi, M., Incollingo, A., \& Bisogno, M. (2019). Disclosure of Intellectual Capital Components in Integrated Reporting: An Empirical Analysis. Sustainability, 11(1), 1-15. https://doi.org/10.3390/su11010062

Serafeim, G. (2015). Integrated Reporting and Investor Clientele. Journal of Applied Corporate Finance, 27(2), 34-51. https://doi.org/10.1111/jacf.12116

Sierra-García, L., Zorio-Grima, A., \& García-Benau, M. A. (2015). Stakeholder engagement, corporate social responsibility and integrated reporting: an exploratory study. Corporate Social Responsibility and Environmental Management, 22(5), 286-304. https://doi.org/10.1002/csr.1345

Stacchezzini, R., Melloni, G., \& Lai, A., (2016). Sustainability management and reporting: the role of integrated reporting for communicating corporate sustainability management. Journal of Cleaner Production, 136, 102-110. https://doi.org/10.1016/j.jclepro.2016.01.109

Strano, E., \& Kabli, A. (2018, July). Non-Financial Reporting in Banks: Emerging Trends in Italy. In 15th International Conference on Social Sciences, Proceedings, 2, 301-307.

Stubbs, W., \& Higgins, C. (2014). Integrated Reporting and internal mechanism of change. Accounting, Auditing and Accountability Journal, 27(7), 1068-1089. https://doi.org/10.1108/AAAJ-03-2013-1279

Thomson, I. (2015). But does sustainability need capitalism or an integrated report' a commentary on 'The International Integrated Reporting Council: A story of failure' by Flower J. Critical Perspectives on Accounting, 27, 18-22. https://doi.org/10.1016/j.cpa.2014.07.003

Van Bommel, K. (2014). Towards a legitimate compromise? An exploration of Integrated Reporting in the Netherlands. Accounting, Auditing and Accountability Journal, 27(7), 1157-1189. https://doi.org/10.1108/AAAJ-04-2013-1309

Vaz, N., Fernandez-Feijoo, B., \& Ruiz, S. (2016). Integrated reporting: an international overview. Business Ethics: A European Review, 25(4), 577-591. https://doi.org/10.1111/beer.12125

Velte, P., \& Stawinoga, M. (2017). Integrated Reporting: The Current State of Empirical Research, Limitations and Future Research Implications. Journal of Management Control, 28(3), 275-320. https://doi.org/10.1007/s00187-016-0235-4

Venturelli, A., Cosma, S., \& Leopizzi, R. (2018). Stakeholder engagement: An evaluation of European banks. Corporate Social Responsibility and Environmental Management, 25(4), 690-70. https://doi.org/10.1002/csr.1486

Vitolla, F., Raimo, N., \& Rubino, M. (2019). Appreciations, criticisms, determinants, and effects of integrated reporting: A systematic literature review. Corporate Social Responsibility and Environmental Management, 26(2), 518-528. https://doi.org/10.1002/csr.1734

Weber, R. P. (1990). Basic Content Analysis (2nd ed.), Sage, London.

Wild, S., \& Van Staden, C. (2013). Integrated reporting: initial analysis of early reporters-an institutional theory approach, 7th Asia Pacific Interdisciplinary Accounting Research Conference (pp. 26-28).

Zambon, S., \& Marzo, G. (2007). Visualising Intangibles: Measuring and Reporting in the Knowledge Economy. Ashgate, Farnham.

Zhou, S., Simnett, R., \& Green, W. (2017). Does integrated reporting matter to the capital market? Abacus, 53(1), 94-132. https://doi.org/10.1111/abac.12104

\section{Note}

Note 1. See http://examples.integratedreporting.org/all_organizations 


\section{Appendix A}

The list of 45 firms

\begin{tabular}{|c|c|c|c|c|c|}
\hline 1 & Achmea & 16 & Generali & 31 & Road Accident Fund \\
\hline 2 & Aegon & 17 & Hammerson & 32 & Rsa \\
\hline 3 & Banca Fideuram & 18 & Hsbc & 33 & Sanlam Ltd. \\
\hline 4 & Bank of Ceylon & 19 & Idlc Finance & 34 & Sasria \\
\hline 5 & Bankmecu & 20 & Ing & 35 & Standard Bank Group Ltd \\
\hline 6 & Barclays Africa Group & 21 & ItaùUnibanco Holding S.A. & 36 & Stockland \\
\hline 7 & Bndes & 22 & Lb Finance & 37 & Strate \\
\hline 8 & British Land & 23 & Liberty Holdings & 38 & Swedfund \\
\hline 9 & Capricorn Group & 24 & Lloyds Banking Group & 39 & Swedish Export Credit C. \\
\hline 10 & Ccr Sa & 25 & Mitusiand Co & 40 & Triodos \\
\hline 11 & Dbs & 26 & Ms and Ad Insurance Group H. & 41 & Tskb \\
\hline 12 & Dbsa & 27 & National Australia Bank & 42 & Ubs \\
\hline 13 & Direct Line Group & 28 & Nedbank & 43 & Unicredit \\
\hline 14 & Eurazeo & 29 & Peoples Leasing and Finance & 44 & Unipol \\
\hline 15 & Fnb Namibia Holdings & 30 & Redefine International & 45 & Vancity \\
\hline
\end{tabular}

\section{Copyrights}

Copyright for this article is retained by the author(s), with first publication rights granted to the journal.

This is an open-access article distributed under the terms and conditions of the Creative Commons Attribution license (http://creativecommons.org/licenses/by/4.0/). 